\title{
Distribution of Chemical Species in the Water-Soil-Plant (Carya illinoiensis) System near a Mineralization Area in Chihuahua, Mexico-Health Risk Implications
}

\author{
Angélica Cervantes-Trejo, Carmelo Pinedo-Álvarez, Eduardo Santellano-Estrada (iD, \\ Leonor Cortes-Palacios and Marusia Rentería-Villalobos * (iD) \\ Departament of Natural Resources, Facultad de Zootecnia y Ecología, \\ Universidad Autonoma de Chihuahua (UACH), Perif. Fco. R. Almada Km 1, 31453 Chihuahua, Mexico; \\ angelica.cervantes@cimav.edu.mx (A.C.-T.); cpinedo@uach.mx (C.P.-Á.); esantellano@uach.mx (E.S.-E.); \\ lcortes@uach.mx (L.C.-P.) \\ * Correspondence: mrenteria@uach.mx; Tel.: +52-614-4340304
}

Received: 9 June 2018; Accepted: 26 June 2018; Published: 2 July 2018

\begin{abstract}
The aim of this study was to quantify major and trace elements in the water, soil, and plants (Carya illionensis) in an agricultural area; and to determine the health risks associated with the walnuts ingestion by calculating the risk quotient. Samples of water, soil, tree leaves, and walnuts were collected; in total, 135 samples were analyzed. Physicochemical parameters were obtained in irrigation water and soil samples. Elemental measurements were performed in an ICP, -OES and -MS. In addition, the distribution coefficient (soil-water), transfer factor (soil-plant), and hazard quotient were evaluated. In the irrigation water, $\mathrm{As}, \mathrm{Cr}$, and $\mathrm{Pb}$, showed concentrations above the maximum allowable limits. Likewise, high concentrations of $\mathrm{As}, \mathrm{Cr}, \mathrm{Pb}$, and $\mathrm{Sb}$ were found in tree leave samples, indicating a possible tendency of hyperaccumulation of those elements. Furthermore, $\mathrm{Cr}$ concentrations in walnuts were high by far than the reference value (FAO/WHO). A possible competition between chemical congeners were detected from transfer factors. Although, $\mathrm{Sb}$ concentrations in walnuts were also high, and no legislation for it in fruits exists. The hazard risk quotient for $\mathrm{Sb}$ did indicate a potential health risk. Finally, it is important to consider that the health risk increases when exposure through consumption takes place over a prolonged period of time, even in low concentrations.
\end{abstract}

Keywords: toxic elements; transfer factor; bioaccumulation; hazard risk quotient

\section{Introduction}

The occurrence and distribution of trace elements, even in low concentrations, represents a risk for ecosystems and human health [1]. The composition of these elements in nature depends on their local mineralization, interactions with the environment, soil, and water, and the specific biota of each site [2]. The environmental problems caused by trace elements are the result of their natural mobilization, lithology, weathering reactions, biological activity, volcanic emissions, rock solubilization, and anthropogenic activity [3,4]. Trace elements are directly emitted into the atmosphere and the soil, due to the emission of mining residues, industrial emissions, the use of pesticides and fertilizers, fossil fuels, and wood preservatives [4]. Trace metal contamination of food is one of the main aspects of food quality $[5,6]$.

Heavy metals are the most dangerous because they are not chemically or biologically degradable, and because of the accumulation in living organisms $[7,8]$. The toxicity of trace elements varies from 
one element to the other. The accumulation of heavy metals has been reported to produce carcinogenic, mutagenic, and teratogenic effects-which are associated with cardiovascular, kidney, and osseous diseases-and nervous system disorders that may lead to harmful effects on the circulatory, enzymatic, endocrine, immunological, and central nervous systems [9,10].

The distribution of trace elements in nutrients that results from transformation, retention, and transport processes is different for every vegetable species. In the soil, the concentration of these elements is regulated by interrelated processes, including organic and inorganic complexation, oxidation-reduction reactions, precipitation-dissolution reactions, and absorption-desorption reactions [11]. These processes depend on the different chemical and environmental conditions, such as $\mathrm{pH}$, electric conductivity, study site, geology of the agricultural soil, and degradation of the organic matter, among other processes [12]. The potential of plants to absorb trace elements and nutrients depends on the bioavailability of these elements in the soil, the age of the vegetal species, and the capacity of the plant to absorb, transport, and accumulate the elements in their roots and aerial parts, which is different for every vegetal species $[5,9,13]$. Therefore, it is necessary to identify the contaminants to evaluate their potential sources [14].

In Aldama, Chihuahua, Mexico (northern Mexico), a U mining operation began in the 1970s in the district of Pena Blanca. Here, the exploitation process and associated water-soil interactions resulted in the release of potentially toxic elements. Because the area of the mine is located near an agricultural area, mainly walnut orchards, the exposure to uranium and other toxic elements is of particular concern. Specifically, there exists no information on the distribution of trace elements and nutrients in walnut trees. In order to minimize adverse effects, it is important to continuously monitor the levels of trace elements in food [6]. The aim of this study was to quantify major and trace elements in the water, soil, and plants (Carya illionensis) in an agricultural area in Aldama, Chihuahua; and to determine the health risks associated with the ingestion of walnuts by calculating the risk quotient for each of the elements under analysis.

\section{Materials and Methods}

\subsection{Study Area}

The study area is located between latitude $28^{\circ} 50^{\prime} 00^{\prime \prime} \mathrm{N}$ and longitude $105^{\circ} 53^{\prime} 00^{\prime \prime} \mathrm{W}$ in the city of Aldama, Chihuahua, Mexico. In this area, semiarid conditions prevail with annual average precipitation of $336 \mathrm{~mm}$. The Peña Blanca Uranium District is located to the west of the study area. The region is dominated by an alternating sequence of high country and watersheds that run from west to east. The Peña Blanca range developed from cratonic block towards the west during the Cenozoic Era. Specifically, it is located on a strip of hydrothermal uranium fields in a semiarid region from where a section of limestones, mudstones, sandstones, and tertiary rhyolitic tuffs originates that covers carbonated rocks that underwent tectonic deformations [15]; those rocks are found in a chemically oxidative and unsaturated zone, at $200 \mathrm{~m}$ over the water table. The local hydrology depends on the regional hydrological setting, and the groundwater system behaves as an unconfined aquifer [16]. In this region, the groundwater is the main water source for use and consumption by the population. The area of study and the sampling points are showed in Figure 1.

\subsection{Sampling}

The study took place in five walnut orchards: La Aurora, El Edén, Los Laureles, Santa Lucía, and Viña Grande. Sampling took place in October 2015 prior to harvest. Samples of water, soil, walnut tree leaves, and walnuts were collected in every walnut orchard; in total 135 samples were collected. Water was sampled from wells, except for Viña Grande where the irrigation is from surface water (river). Water samples were collected in a $1 \mathrm{~L}$ container, where in situ parameters such as $\mathrm{pH}$, electrical conductivity (EC), temperature (T), and total dissolved solids (TDS) were measured. Soil samples were taken from an area of $30 \times 30 \mathrm{~cm}$ at a depth of $0-30 \mathrm{~cm}$. Samples of $1 \mathrm{~kg}$ of soil, leaves, and walnuts were 
collected in a plastic bag for further analyses in the laboratory. In soil samples, $\mathrm{pH}, \mathrm{EC}$, and $\mathrm{T}$ parameters were measured. In addition, these samples were air-dried, crushed to a fine powder (200 mesh), and homogenized. Leaves and walnut samples were first thoroughly washed with tap water, and finally with deionized water, to remove impurities. In walnut samples, the shell was separated. Afterwards, samples of leaves, walnuts, and shells were ground in a glass mortar and sieved to obtain a fine powder. Finally, samples of soil, leaves, walnuts, and shells were dried in an oven to $75 \pm 5{ }^{\circ} \mathrm{C}$ for $24 \mathrm{~h}$.
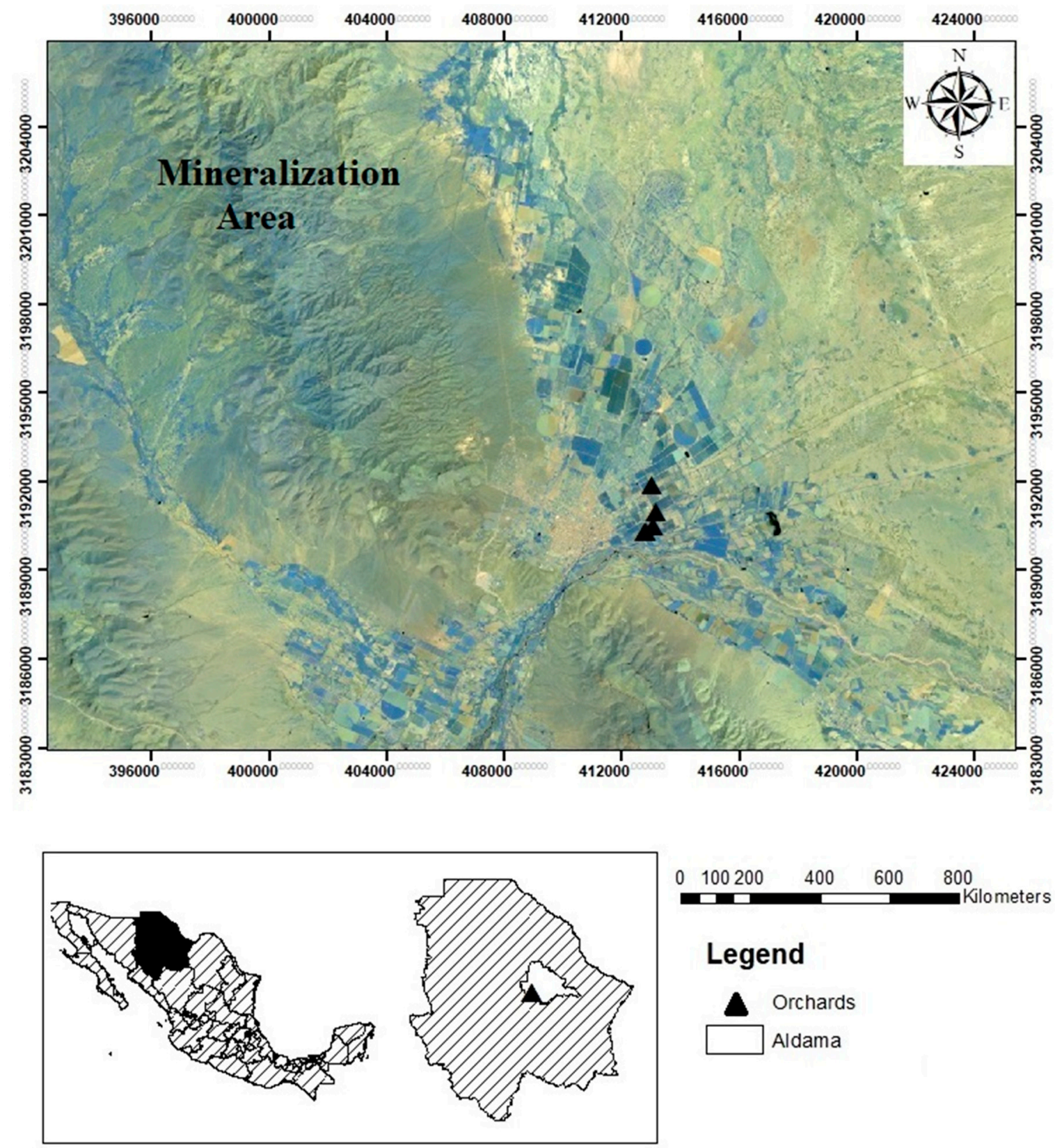

\section{Legend}

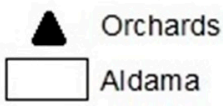

Figure 1. Location of the area of study and the sampling points selected in Aldama, Chihuahua.

\subsection{Experimental Procedure}

An aliquot of soil (500 mg), leaves (200 mg), shells (250 mg), walnut (250 mg), and groundwater $(2 \mathrm{~mL})$ samples was taken and transferred to a poly vial (tetrafluoroethylene, PTFE). Samples were subjected to acid digestion by using different reagents. For soils and leaves, $2 \mathrm{~mL}$ of $\mathrm{HCl}(36.5-38 \%$ J.T. Baker), $8 \mathrm{~mL}$ of $\mathrm{HNO}_{3}(65 \%)$, and $0.5 \mathrm{~mL}$ of $\mathrm{H}_{2} \mathrm{O}_{2}(30 \%$, J.T. Baker) were added to the aliquots. 
For shells and walnuts, $4 \mathrm{~mL}$ of $\mathrm{HNO}_{3}\left(65.8 \%\right.$, J.T. Baker) and $2 \mathrm{~mL}$ of $\mathrm{H}_{2} \mathrm{O}_{2}$ were added to the aliquots. Finally, for groundwater $9 \mathrm{~mL}$ of $\mathrm{HCl}$ and $3 \mathrm{~mL}$ of $\mathrm{HNO}_{3}$ were added to the aliquots. Digestion of samples was performed using a microwave digestor (Multiwave GO, Anton Paar, Graz, Austria). Elemental measurements were performed in an ICP-OES (iCAP 6500, Thermo Scientific ${ }^{\circledR}$, Waltham, MA, USA) and ICP-MS (NexION 300D, PerkinElmer ${ }^{\circledR}$, Waltham, MA, USA). The standard solutions were prepared from $1000 \mathrm{mg} / \mathrm{L}$ of each element (National Institute of Standards and Technology, NIST; Gaithersburg, MD, USA) for detection by ICP-MS (iCAP 6500, Thermo Scientific ${ }^{\circledR}$ ) and ICP-OES (NexION 300D, Perkin Elmer ${ }^{\circledR}$ ). All measurements were performed in triplicates. The elements As, Ca, $\mathrm{Cd}, \mathrm{Cr}, \mathrm{Cu}, \mathrm{Fe}, \mathrm{K}, \mathrm{Mg}, \mathrm{Mn}, \mathrm{P}, \mathrm{Pb}, \mathrm{S}, \mathrm{Sb}$, and $\mathrm{Zn}$ were obtained using ICP-OES, while $\mathrm{U}$ was measured by ICP-MS. The ICP-OES detection limit for elements analyzed is in the order of $\mathrm{ppb}(\mu \mathrm{g} / \mathrm{L})$ : As (1.4), $\mathrm{Ca}$ (0.58), Cd (0.05), Cr (0.15), Cu (0.69), Fe (0.25), K (0.6), Mg (0.3), Na (0.37), P (1.55), Pb (1.1), S (1.05), $\mathrm{Sb}$ (1.1), and $\mathrm{Zn}(0.19)$.

\subsection{Distribution Coefficient (Kd)}

The distribution and/or fractioning of chemical species between the solid-solution system is described by the distribution coefficient $(\mathrm{kd})[17,18]$. This coefficient expresses the amount of absorbed chemical species for every unit of mass of the solid, divided by the amount of the same chemical species dissolved in the liquid. In general, this is expressed by the equation [19]

$$
\mathrm{kd}=\mathrm{Cs} / \mathrm{Cw}
$$

where $\mathrm{Cs}$ is the element concentration in the soil $(\mathrm{mg} / \mathrm{kg})$ and $\mathrm{Cw}$ is the element concentration in water $(\mathrm{mg} / \mathrm{L})$.

Some factors that affect $\mathrm{kd}$ are; climatic conditions, soil characteristics, temperature, $\mathrm{pH}$, ionic, and physical form of the chemical species, as well as the presence of other ions in the medium under study. The different ionic species are absorbed at different speeds; absorption of cations is generally stronger (large $\mathrm{kd}$ ) compared to anions, due to the dominance of negatively charged particles on the surface of the solids.

\subsection{Transfer Factors}

The uptake of elements from soil to plants is measured by the transfer factor (TF). The TF for any given element can vary considerably depending on the kind of plant, as well as from one environment to another. The main parameters that modify the TF are; physical and chemical characteristics of the soil, trace element behavior in the soil and plant, and environmental changes [20,21]. The TF from soil to plants is calculated using the equation [22-24]

$$
\mathrm{TF}=\mathrm{C}_{\text {plant }} / \mathrm{C}_{\text {soil }}
$$

where $C_{\text {plant }}$ and $C_{\text {soil }}$ refer to the concentration of each element in a specific vegetable or soil, respectively.

\subsection{Statistical Analysis}

In order to identify the statistical behavior of variables obtained, an analysis of variance, correlation analysis, and cluster analysis were performed. The procedure GLM (General Linear Model) in SAS 9 (Statistical Analysis System, 2002) (SAS institute, Cary, NC, USA) was used to obtain the estimators. 


\subsection{Hazard Quotients (HQ)}

In order to estimate the risk from soil-water and vegetable ingestion, hazard quotients (HQs) were calculated using the following equations as reported by Warming [25].

$$
\mathrm{HQ}=\mathrm{EI} / \mathrm{TDI},
$$

where EI refers to the elemental intake of a particular trace element from a specific vegetable, soil, or water; TDI represents the tolerable daily intake values for each trace element $(\mu \mathrm{g})$ per kg of bodyweight. EI was calculated using the equation

$$
\mathrm{EI}=(\mathrm{C} \times \mathrm{CR}) / \mathrm{Bw}
$$

where $C$ refers to the concentration in either a specific vegetable, $C R$ corresponds to the daily consumption of a specific vegetable, and Bw refers to the average bodyweight $(72 \mathrm{~kg})$.

\section{Results}

\subsection{Concentration of Major and Toxic Elements in Soil and Water}

Table 1 shows some physicochemical parameters measured in soil and water samples collected in the study area.

\begin{tabular}{|c|c|c|c|c|c|c|c|c|}
\hline \multirow{3}{*}{ Orchard } & \multirow{3}{*}{ Latitude } & \multirow{3}{*}{ Longitude } & \multirow{2}{*}{\multicolumn{2}{|c|}{$\mathrm{pH}$}} & \multirow{2}{*}{\multicolumn{2}{|c|}{$\begin{array}{c}\mathrm{EC} \\
(\mathrm{mS} / \mathrm{cm})\end{array}$}} & \multirow{3}{*}{$\begin{array}{c}\text { TDS } \\
(\mathrm{mg} / \mathrm{L}) \\
\text { Water }\end{array}$} & \multirow{3}{*}{$\begin{array}{c}\text { Hardness } \\
\left(\mathrm{mgCaCO}_{3} / \mathrm{L}\right) \\
\text { Water }\end{array}$} \\
\hline & & & & & & & & \\
\hline & & & Soil & Water & Soil & Water & & \\
\hline La Aurora & $28^{\circ} 51^{\prime} 12.29^{\prime \prime}$ & $105^{\circ} 53^{\prime} 30.93^{\prime \prime}$ & 8.66 & 7.62 & 0.15 & 0.88 & 450 & 3925 \\
\hline El Edén & $28^{\circ} 50^{\prime} 20.94^{\prime \prime}$ & $105^{\circ} 53^{\prime} 38.18^{\prime \prime}$ & 8.18 & 7.55 & 0.15 & 1 & 500 & 4040 \\
\hline Los Laureles & $28^{\circ} 50^{\prime} 27.57^{\prime \prime}$ & $105^{\circ} 53^{\prime} 29.06^{\prime \prime}$ & 8.79 & 7.7 & 0.16 & 0.18 & 590 & 5249 \\
\hline Santa Lucía & $28^{\circ} 50^{\prime} 43.00^{\prime \prime}$ & $105^{\circ} 54^{\prime} 25.82^{\prime \prime}$ & 8.5 & 6.66 & 0.2 & 0.78 & 390 & 4771 \\
\hline Viña Grande & $28^{\circ} 50^{\prime} 21.57^{\prime \prime}$ & $105^{\circ} 53^{\prime} 40.33^{\prime \prime}$ & 8.45 & 8.0 & 0.15 & 1.12 & 560 & 4161 \\
\hline
\end{tabular}

Table 1. Chemical parameters measured in situ in the different soils and irrigation water of the orchards.

The water $\mathrm{pH}$ presented values with a tendency to neutral, with a maximum value of 8 , whereas the soil showed $\mathrm{pH}$ values of 8.2 to 8.8 . The EC in water showed higher values than in soil, from 0.2 to $1.1 \mathrm{mS} / \mathrm{cm}$. In water, the TDS and hardness showed maximum values of $590 \mathrm{mg} / \mathrm{L}$ and $5249 \mathrm{mgCaCO}_{3} / \mathrm{L}$, respectively. The averaged heavy metal and trace metal concentrations in soils and irrigation water from five walnut orchards close the uranium district are shown in Table 2. It can be seen that the soil contains high concentrations of $\mathrm{Fe}, \mathrm{Ca}, \mathrm{K}, \mathrm{Mn}, \mathrm{Na}, \mathrm{P}, \mathrm{S}$, and $\mathrm{Zn}$. In addition, in water the elements with higher concentrations were $\mathrm{Ca}, \mathrm{Na}$, and $\mathrm{S}$.

\subsection{Concentration of Major and Toxic Elements in Carya illionensis}

The averaged trace elemental concentrations in leaves, shells, and walnut samples from five walnut orchards close the uranium district are shown in Table 3. Results are the average concentration in every component of Carya illionensis.

From the results, it may observed that $\mathrm{As}$ an $\mathrm{Pb}$ were no found in walnut and shell. Likewise, $\mathrm{Cu}$ was not present in walnut. Cd was only detected in leaves and shells collected from La Aurora orchard. Elements with high concentration $(>1000 \mathrm{mg} / \mathrm{kg})$ in leaves were $\mathrm{Ca}>\mathrm{K}>\mathrm{Mg}>\mathrm{S}=\mathrm{P}$, in walnuts were $\mathrm{K}>\mathrm{P}>\mathrm{Mg}>\mathrm{S}>\mathrm{Ca}$, and in shell were only $\mathrm{Ca}$. 
Table 2. Averages of elemental content $(\mu \mathrm{g} / \mathrm{g})$ in soil and irrigation water, as well as their SD.

\begin{tabular}{|c|c|c|c|c|c|c|c|c|c|c|c|c|}
\hline \multirow{2}{*}{$\begin{array}{l}\text { Orchard } \\
\text { Element }\end{array}$} & \multicolumn{2}{|c|}{ La Aurora } & \multicolumn{2}{|c|}{ El Edén } & \multicolumn{2}{|c|}{ Laureles } & \multicolumn{2}{|c|}{ Santa Lucía } & \multicolumn{2}{|c|}{ Viña Grande } & \multicolumn{2}{|c|}{$\begin{array}{c}\mathrm{AL} \\
\text { Irrigation }\end{array}$} \\
\hline & Soil & Water & Soil & Water & Soil & Water & Soil & Water & Soil & Water & ALa & ALb \\
\hline As & $7.7 \pm 0.4$ & $4.2 \pm 0.2$ & $13 \pm 1.1$ & $1 \pm 0$ & $12.7 \pm 1.3$ & $<$ LOD & $12.2 \pm 0.4$ & $<\mathrm{LOD}$ & $12.8 \pm 1.2$ & $0.5 \pm 0.01$ & 0.4 & 0.1 \\
\hline $\mathrm{Ca}$ & $6671 \pm 491$ & $1351 \pm 112$ & $8121 \pm 238$ & $1398 \pm 79$ & $6830 \pm 389$ & $1723 \pm 131$ & $6444 \pm 311$ & $1465 \pm 172$ & $8003 \pm 265$ & $1387 \pm 117$ & - & - \\
\hline $\mathrm{Cd}$ & $2.7 \pm 0.3$ & $<\mathrm{LOD}$ & $3.2 \pm 0.3$ & $<\mathrm{LOD}$ & $2.4 \pm 0.3$ & $<\mathrm{LOD}$ & $2.4 \pm 0.5$ & $<\mathrm{LOD}$ & $3.1 \pm 0.4$ & $<\mathrm{LOD}$ & - & - \\
\hline $\mathrm{Cr}$ & $48 \pm 1$ & $31 \pm 1$ & $46 \pm 3$ & $34 \pm 1$ & $46 \pm 4$ & $34 \pm 1$ & $39 \pm 2$ & $32 \pm 2$ & $45 \pm 1$ & $35 \pm 1$ & 1 & 0.1 \\
\hline $\mathrm{Cu}$ & $10.7 \pm 1.1$ & $<\mathrm{LOD}$ & $21.2 \pm 1.9$ & $<\mathrm{LOD}$ & $10 \pm 1.4$ & $<\mathrm{LOD}$ & $7.5 \pm 0.3$ & $<\mathrm{LOD}$ & $15.6 \pm 1.7$ & $<\mathrm{LOD}$ & - & - \\
\hline $\mathrm{Fe}$ & $17,753 \pm 1372$ & $181 \pm 7$ & $20,358 \pm 787$ & $188 \pm 6$ & $16,478 \pm 1113$ & $193 \pm 11$ & $17,897 \pm 987$ & $205 \pm 22$ & $19,482 \pm 1642$ & $181 \pm 3$ & - & - \\
\hline K & $4682 \pm 477$ & $161 \pm 21$ & $5244 \pm 480$ & $34 \pm 0.4$ & $3332 \pm 210$ & $14 \pm 5$ & $3770 \pm 160$ & $28 \pm 2$ & $5109 \pm 195$ & $45 \pm 5$ & - & - \\
\hline $\mathrm{Mg}$ & $3998 \pm 469$ & $135 \pm 3$ & $5751 \pm 520$ & $231 \pm 2$ & $4178 \pm 159$ & $272 \pm 12$ & $4487 \pm 485$ & $170 \pm 12$ & $5806 \pm 209$ & $159 \pm 24$ & - & - \\
\hline $\mathrm{Mn}$ & $499.4 \pm 9$ & $0.9 \pm 0.1$ & $508.8 \pm 33.8$ & $0.4 \pm 0$ & $375.2 \pm 11.2$ & $0.3 \pm 0.004$ & $396.1 \pm 32.3$ & $0.3 \pm 0.1$ & $509.8 \pm 15$ & $0.9 \pm 0.002$ & - & 0.2 \\
\hline $\mathrm{Na}$ & $492.4 \pm 46$ & $895 \pm 12$ & $520.8 \pm 38$ & $892 \pm 9$ & $505 \pm 47$ & $975 \pm 59$ & $500 \pm 10$ & $901 \pm 102$ & $516 \pm 43$ & $1507 \pm 42$ & - & - \\
\hline $\mathrm{P}$ & $383.5 \pm 11.7$ & $7.5 \pm 1.1$ & $2256 \pm 183.9$ & $<\mathrm{LOD}$ & $437 \pm 33.5$ & $5.6 \pm 0.3$ & $411 \pm 89.5$ & $8 \pm 0.1$ & $2178 \pm 32.7$ & $14 \pm 1$ & - & - \\
\hline $\mathrm{Pb}$ & $<$ LOD & $11.5 \pm 8.2$ & $45.2 \pm 5$ & $<\mathrm{LOD}$ & $28.1 \pm 2.4$ & $8.6 \pm 0.2$ & $30.6 \pm 2.7$ & $4.5 \pm 0.3$ & $47.4 \pm 2.7$ & $<$ LOD & 10 & 5 \\
\hline $\mathrm{S}$ & $195 \pm 1$ & $375 \pm 10$ & $304 \pm 18$ & $361 \pm 5$ & $202 \pm 14$ & $442 \pm 4$ & $135 \pm 29$ & $291 \pm 15$ & $300 \pm 14$ & $371.5 \pm 34$ & - & - \\
\hline $\mathrm{Sb}$ & $6.8 \pm 1.4$ & $5.2 \pm 2.8$ & $7.9 \pm 1.6$ & $<\mathrm{LOD}$ & $6.4 \pm 1.2$ & $<\mathrm{LOD}$ & $7 \pm 1.5$ & $<\mathrm{LOD}$ & $8 \pm 1.1$ & $<\mathrm{LOD}$ & - & - \\
\hline $\mathrm{U}$ & $1.5 \pm 0.1$ & $<\mathrm{LOD}$ & $0.407 \pm 0.02$ & $<\mathrm{LOD}$ & $0.997 \pm 0.06$ & $<\mathrm{LOD}$ & $0.861 \pm 0.03$ & $<\mathrm{LOD}$ & $1.291 \pm 0.09$ & $<\mathrm{LOD}$ & - & - \\
\hline $\mathrm{Zn}$ & $82.4 \pm 0.3$ & $0.5 \pm 0.01$ & $146.7 \pm 7.8$ & $2.7 \pm 0.3$ & $61.5 \pm 3.1$ & $<\mathrm{LOD}$ & $60.6 \pm 8.1$ & $2.7 \pm 0.08$ & $148.5 \pm 5.5$ & $0.9 \pm 0.01$ & 20 & 2 \\
\hline
\end{tabular}

$\mathrm{ALa}=$ Allowed limit by CONAGUA [26]. ALb = Allowed limit by FAO [27]. <LOD = result lower than the limits of detection of ICP-OES/ICP-MS. - there is not allowed limit stablished by agencies. 
Table 3. Averages of elemental content (range; $\mathrm{mg} / \mathrm{kg}$ ) in leaves, walnut, and shells samples.

\begin{tabular}{cccc}
\hline Element & Leaves & Walnut & Shell \\
\hline $\mathrm{As}$ & $8.9(0.001-14.6)$ & $<\mathrm{LOD}$ & $<\mathrm{LOD}$ \\
$\mathrm{Ca}$ & $17,914(16,301-18,721)$ & $967(769-1466)$ & $6175(4948-6796)$ \\
$\mathrm{Cr}$ & $53(2.5-76)$ & $8.9(8-10)$ & $8.8(1.5-16.2)$ \\
$\mathrm{Cu}$ & $13(10-16)$ & $3.4(0.5-6.3)$ & $<\mathrm{LOD}$ \\
$\mathrm{Fe}$ & $551(282-669)$ & $80(75-90)$ & $47(24-73)$ \\
$\mathrm{K}$ & $16,166(11,997-24,541)$ & $4457(3926-5794)$ & $2675(1969-3586)$ \\
$\mathrm{Mg}$ & $5010(3691-6275)$ & $1423(1268-1579)$ & $430(337-574)$ \\
$\mathrm{Mn}$ & $553(241-936)$ & $53(33-73)$ & $43(19-70)$ \\
$\mathrm{Na}$ & $433(232-563)$ & $206(198-217)$ & $203(130-243)$ \\
$\mathrm{P}$ & $1933(1186-2685)$ & $2981(2696-3293)$ & $270(140-395)$ \\
$\mathrm{Pb}$ & $10(5-14)$ & $<\mathrm{LOD}$ & $<\mathrm{LOD}$ \\
$\mathrm{S}$ & $2375(1559-2806)$ & $1090(992-1155)$ & $159(129-186)$ \\
$\mathrm{Sb}$ & $5(0.5-9.1)$ & $2.5(1.3-5.3)$ & $3.2(0.001-5.8)$ \\
$\mathrm{U}$ & $0.4(0.1-1.3)$ & $0.042(0.001-0.1)$ & $0.041(0.001-0.1)$ \\
$\mathrm{Zn}$ & $237(44-536)$ & $61(45-75)$ & $4.1(1.1-6.9)$ \\
\hline
\end{tabular}

$<\mathrm{LOD}=$ result lower than the limits of detection of ICP-OES/ICP-MS.

\section{Discussion}

The study area contains soils with a slightly basic pH from 8.2 to 8.8 (Table 1), which can be attributed to the low annual precipitation in arid zones. Soil properties can influence the transfer of ions from the soil to the plant; previous studies indicate that the accumulation of heavy metals in the soil can be affected by the $\mathrm{pH}$ of the soil [28]. The hardness levels of the water do not present maximum allowable rates. However, the values that were found in the orchards under study are considered high; these values represent high salt concentrations in the water. The $\mathrm{pH}, \mathrm{EC}$ and $\mathrm{T}$ values obtained from soil and irrigation water were statistically different.

The mobility of trace elements in the soil is complex and can be attributed to a variety of factors [3]: physicochemical properties, chemical species, climate, biological activity, and their interactions. The present study focused on the mobility of nutrients and trace elements with respect to physicochemical properties ( $\mathrm{pH}, \mathrm{CE}$, analyte concentrations).

\subsection{Element Characterization in Water}

Trace elements such as $\mathrm{As}, \mathrm{Cr}, \mathrm{Pb}$, and $\mathrm{Sb}$ are highly toxic to the environment. Moreover, the irrigation of soils with water that contains high concentrations of trace elements not only results in the transfer of these elements from the water to the soil, but also increases the bioavailability of these elements for plants [4]. In Table 2, it can be observed that the concentrations of these elements in the irrigation water that was analyzed in this study are above the recommended maximum concentration for irrigation water [26,27]. It was determined that the orchards La Aurora, El Eden, and Viña Grande presented As values of 4.2,1.0, and $0.5 \mathrm{mg} / \mathrm{L}$, respectively, which is higher than the maximum allowable concentration for irrigation water. It is known that in Argentina there is an important problem with the As concentrations in water. Some authors have reported values as high as $1.43 \mathrm{mg} / \mathrm{L}$ for water originating from a river [3]. Furthermore, in China As values of $0.01424 \mathrm{mg} / \mathrm{L}$ and $0.077 \mathrm{mg} / \mathrm{L}$ were reported in irrigation water from a river and a well, respectively [29]. These values are similar to the concentrations in this study. Moreover, the values in La Aurora are higher than these values. Cr was found in a range from 31.1 to $34.6 \mathrm{mg} / \mathrm{L}$ in the analyzed water samples. These values are higher than the maximum values allowed according to national and international legislations. The specie $\mathrm{Cr}(\mathrm{VI})$ is the most toxic specie, the concentration obtained in the present study is for total Cr. In irrigation water for agricultural areas, reported values of $\mathrm{Cr}$ range from 0.00236 to $0.31 \mathrm{mg} / \mathrm{L}$ [22,29]. Moreover, $\mathrm{Cr}$ values in irrigation water from a contaminated river in Argentina were found to vary between 1.67 and $11.51 \mathrm{mg} / \mathrm{L}$ [3]. The $\mathrm{Cr}$ values that were obtained in the present study are higher than 
the concentrations reported in those studies. Furthermore, in the orchard La Aurora the average $\mathrm{Pb}$ concentration was $11.5 \mathrm{mg} / \mathrm{L}$, passing the established regulations for this element in irrigation water [26,27], whereas the $\mathrm{Pb}$ concentration in the orchard Los Laureles was $8.5 \mathrm{mg} / \mathrm{L}$, passing the FAO regulation [27]. In related studies on the concentrations of $\mathrm{Pb}$ in irrigation water, maximum values of $0.00218 \mathrm{mg} / \mathrm{L}$ and $0.00435 \mathrm{mg} / \mathrm{L}$ were reported for river water and well water, respectively [29]. In the orchard La Aurora an average Sb concentration of $5.2 \mathrm{mg} / \mathrm{L}$ was found. However, there is no maximum allowable limit for $\mathrm{Sb}$ in the legislation for irrigation water. In other studies, $\mathrm{Sb}$ values of 0.00178 to $0.0052 \mathrm{mg} / \mathrm{L}$ have been reported for irrigation water [29-31].

Finally, another element for which the concentration was found to pass the established norm by FAO was Mn [32]. Mn does not present a risk to human health. However, high concentrations of Mn in irrigation water can be transferred to the soil, in this matrix they can oxidize and absorb arsenic species [33]. The Mn concentrations in irrigation water in the present study ranged from 0.3 to $0.9 \mathrm{mg} / \mathrm{L}$; these values are higher than the maximum allowable concentration of $0.2 \mathrm{mg} / \mathrm{L}$. Mn values in superficial irrigation water that have been reported in the literature are found in an interval of concentrations from 0.0446 to $0.219 \mathrm{mg} / \mathrm{L}[3,29,34]$, whereas in well water it was $0.458 \mathrm{mg} / \mathrm{L}$ [29]. Under arid conditions, chemical processes take place over a long time, due to low precipitation regime. However, groundwater is the main source for use and human consumption in the area, inducing to a high water extraction rate from aquifer. Consequently, this process might cause the increase of the toxic element contents in water. Thus, elements such as $\mathrm{As}, \mathrm{Cr}, \mathrm{Pb}$, and $\mathrm{Sb}$ present in groundwater results in increased health risk for the inhabitants.

\subsection{Element Characterization in the Soil}

Currently, there is no legislation for nutrients and trace elements in the soil. However, the reference values for these elements can be obtained from their concentrations in the earth crust; these concentrations may vary depending on the lithology of each specific area. The concentrations of trace elements in the soil that were found in the present study can be considered high in comparison to published studies. The results in Table 2 show high concentrations of Ca in comparison to the average in the earth's crust (4.1\%), which is in agreement with the calcareous soil type of the region [35]. Calcareous soils are usually poor in organic matter content, N, Fe, P, and Zn [27].

In the study region, some elements in stream sediments were determined by the Mexican Geological Service (SGM) [36]. In Table 4, a comparison of the concentrations of $\mathrm{As}, \mathrm{Cu}, \mathrm{Pb}, \mathrm{Sb}$, and $\mathrm{Zn}$ is shown between what was published by SGM and what was found in the present study.

Table 4. Comparison of soil ranges, present study and SGM values.

\begin{tabular}{ccc}
\hline Element & Concentration of Present Study $(\mathbf{m g} / \mathbf{k g})$ & Concentration Found by SGM (mg/kg) \\
\hline $\mathrm{As}$ & $7.7-13$ & $10.33-14.46$ \\
$\mathrm{Cu}$ & $7.48-21.23$ & $6.15-13.31$ \\
$\mathrm{~Pb}$ & $0-47.73$ & $31.88-43.43$ \\
$\mathrm{Sb}$ & $6.44-7.95$ & $1.35-20.02$ \\
$\mathrm{Zn}$ & $60.55-148.83$ & $48.77-96.84$ \\
\hline
\end{tabular}

With the aim of determining if significant differences exist between the mean concentrations shown in Table 4, a Student's $t$-test was performed (95\% confidence level). The results show that there are no significant differences between the means of the analytes. Thus, the values found for these analytes in the present study correspond to what was reported for soil samples by SGM.

Furthermore, some authors obtained $\mathrm{Cr}$ concentrations between 26 and $708 \mathrm{mg} / \mathrm{kg}$ in agricultural soils [5,22]. The $\mathrm{Cr}$ in the soil in the present study falls within the range of these reported values, with a range of concentrations from 38.9 to $48.3 \mathrm{mg} / \mathrm{kg}$. Concentrations of $\mathrm{Sb}$ in the soil were found in a range from 6.4 to $8 \mathrm{mg} / \mathrm{kg}$, which is low compared to $486 \mathrm{mg} / \mathrm{kg}$ that was reported for a contaminated agricultural area [37]. In the present study, $\mathrm{Mn}$ in the soil was found to range from 375.2 to $509.8 \mathrm{mg} / \mathrm{kg}$. A study in a potato agricultural area reported Mn values from 271 to $754 \mathrm{mg} / \mathrm{kg}$ [13]. 
The contents of Fe in the soil is higher than the average of 5\% in the earth's crust [35], which indicates an enrichment of this metal due to the use of crop fertilizers or additives. This is in agreement with results for soils in arid environments, where an average weight of $3 \%$ has been reported [38]. In addition, these authors report $\mathrm{Ca}$ concentrations of up to $11 \%$ weight in the soil, with a Fe/Ca ratio of 0.2 , whereas in the present study this ratio is 2.5 .

Furthermore, the only correlation trend that was observed in this matrix was between $\mathrm{Ca}$ and $\mathrm{Pb}$ $(r=0.75)$. Both elements have an oxidation state of $2+$, for which it is suggested that these elements are present in the form of carbonates and sulphides in the soil.

\subsection{Distribution Coefficient (Kd) of Trace Elements in the Soil/Water}

The results for kd indicate that the majority of elements found here are mainly present in the soil (As, $\mathrm{Ca}, \mathrm{Fe}, \mathrm{K}, \mathrm{Mg}, \mathrm{Mn}, \mathrm{P}, \mathrm{Pb}$, and $\mathrm{Zn}$ ). These elements are mainly associated with oxides/hydroxides or in silicate matrices [39]. However, elements with a $\mathrm{kd}<1$ were mainly found dissolved in water; $\mathrm{Cr}$, $\mathrm{Na}$, and $\mathrm{P}$, indicating the presence of these elements as ions originating from leaching from the soil. Finally, $\mathrm{Sb}$ and $\mathrm{U}$ were only detected in the soil.

\subsection{Element Characterization in Carya illionensis}

The determination of trace metals in the environment and food is an important task for scientists, environmentalists, and nutritionists. Similar to water and soil, foods may also be contaminated with trace metals, due to the increased use of chemical compounds in the industry, mining activities, and fertilizers, among others. The uptake of trace elements, including the natural radionuclides, by plants is of high importance in assessing the pathways of these elements into the environment. The transfer of trace elements may take place in the systems soil-plant and/or water-plant. For the human diet, trace metals can be classified as essential ( $\mathrm{Fe}, \mathrm{Mn}, \mathrm{Cu}, \mathrm{Zn}$, and $\mathrm{Se}$ ), probably essential ( $\mathrm{Ni}, \mathrm{V}$, and $\mathrm{Co}$ ) and potentially toxic (As, $\mathrm{Cd}, \mathrm{Pb}, \mathrm{Hg}$, and $\mathrm{U}$ ). Potentially toxic elements can be extremely harmful, even in low concentrations, when they are ingested for a prolonged period of time. Furthermore, essential metals may also create toxic effects when their intake is very high [40].

\subsubsection{Concentration of Major and Toxic Elements in Leaves}

In general, the elements present in leaves were found in the following order of abundance (Table 3): $\mathrm{Ca}, \mathrm{K}, \mathrm{Mg}$, S, and P > $1000 \mathrm{mg} / \mathrm{kg}$; $\mathrm{Mn}, \mathrm{Zn}, \mathrm{Fe}, \mathrm{Na}$, and $\mathrm{Cr}>100 \mathrm{mg} / \mathrm{kg}$; $\mathrm{Cu}$, As, and $\mathrm{Pb}>10 \mathrm{mg} / \mathrm{kg}$; and finally, $\mathrm{Sb}$ and $\mathrm{U}<10 \mathrm{mg} / \mathrm{kg}$.

The concentrations of As in the leaves were found in a range between 5.3 and $14.6 \mathrm{mg} / \mathrm{kg}$; however, in the orchard La Aurora this analyte was not detected. In the soil, a high $\mathrm{pH}$ solubilizes As and it can be available to plants [41]. Hence, the As concentrations in leaves are higher than those in the soil in the present study. Several authors report a wide interval of As concentrations in tree leaves, from 0.54 to $190 \mathrm{mg} / \mathrm{kg}[3,42,43]$. The values in walnut tree leaves reported in the present study are higher than the majority of As values in leaves of other vegetal species. In addition, $\mathrm{Cr}$ concentrations in walnut tree leaves in the present study are found in a range from 53.3 to $75.7 \mathrm{mg} / \mathrm{kg}$. However, orchard La Aurora has a mean Cr concentration of $2.5 \mathrm{mg} / \mathrm{kg}$. Cr values in tree leaves reported in the literature are found in a range of 4.7 to $13.8 \mathrm{mg} / \mathrm{kg}$. Pb concentrations that have been reported for tree leaves go from 3.8 to $21.5 \mathrm{mg} / \mathrm{kg}[42,44]$. The values of $\mathrm{As}, \mathrm{Cr}$, and $\mathrm{Pb}$ in walnut tree leaves are similar to those reported in the literature for different trees.

Another trace element that is found in a high concentration in the walnut tree leaves in the present study is $\mathrm{Sb}$, ranging from 0.5 to $9.1 \mathrm{mg} / \mathrm{kg}$. It is important to note that there is little information on $\mathrm{Pb}$ in the literature. One study in an agricultural area contaminated with antimony reported $\mathrm{Sb}$ concentrations of $0.31-1 \mathrm{mg} / \mathrm{kg}$ in corn leaves, $0.17-0.80 \mathrm{mg} / \mathrm{kg}$ in carrot leaves, and $<0.02-0.07 \mathrm{mg} / \mathrm{kg}$ in leaves from a sugar plant [37]. Taking this into account, the $\mathrm{Sb}$ values that were found in walnut tree leaves in the present study can be considered high, passing the $\mathrm{Sb}$ values in contaminated sites.

Elements such as $\mathrm{Ca}, \mathrm{Fe}, \mathrm{Mg}$, and $\mathrm{Na}$ are nutrients and micronutrients for the development of the walnut tree. Therefore, as the tree grows, there is an increased transfer of these elements to the aerial 
parts of the tree. In this regard, results for trace elements such as $\mathrm{As}, \mathrm{Cr}, \mathrm{Pb}$, and $\mathrm{Sb}$ in walnut tree leaves show a correlation trend between the age of the trees and the presence of these elements in the leaves. This may also be attributed to the walnut trees being located in a semiarid region with high concentrations of salts in the soil, mainly $\mathrm{CaCO}_{3}$. High concentrations of carbonates limit the availability of these micronutrients, for which a common management practice is the addition of $\mathrm{Fe}, \mathrm{P}, \mathrm{N}$, and $\mathrm{Zn}$ via foliar irrigation [45]. The orchard La Aurora contains the youngest trees, with an average age of 20 years, in comparison to the other orchards in this study. Therefore, the low concentrations of trace elements can be attributed to the age of the trees. In contrast, $\mathrm{Cd}$ and $\mathrm{Cu}$ concentrations were higher in younger trees.

\subsubsection{Concentration of Major and Toxic Elements in Shells and Walnuts}

Nuts are both cholesterol-free and rich in important nutrients including proteins, and unsaturated fatty acids [46]. They also contain important micronutrients such as folic acid and niacin, vitamins (E and B6), and minerals such as $\mathrm{Ca}, \mathrm{Mg}, \mathrm{Mn}, \mathrm{Cu}, \mathrm{Fe}, \mathrm{Zn}, \mathrm{Se}, \mathrm{P}$, and $\mathrm{K}$ [47-49].

In general, elements such as $\mathrm{Cr}, \mathrm{Cu}, \mathrm{Fe}, \mathrm{K}, \mathrm{Mg}, \mathrm{P}, \mathrm{S}, \mathrm{U}$, and $\mathrm{Zn}$ were mainly found in the walnut. In contrast, $\mathrm{Ca}$ and $\mathrm{Sb}$ were concentrated in the shell. Furthermore, $\mathrm{Pb}$ was not detected in the shell or the nut. In the shell, the Ca content was lowest in orchard La Aurora, with an average concentration of $4948 \mathrm{mg} / \mathrm{kg}$. In contrast, the Ca concentration in the nut was the highest in these trees. This confirms that the age of the trees plays and important role in the metabolic processes of the plant. The behavior of the macronutrients and $\mathrm{P}$ and $\mathrm{K}$, and the micronutrient $\mathrm{Zn}$ is similar to that of $\mathrm{Ca}$.

Some values for major and trace elements have been reported for walnut shells. These authors found that the concentrations in the shell in percent of mass decreases in the following order $\mathrm{K}>\mathrm{Ca}>\mathrm{Mg}$ $>\mathrm{Al}=\mathrm{Fe}>\mathrm{Na}$ [48]. Furthermore, trace elements were found in the following order of abundance; $\mathrm{Cu}, \mathrm{Zn}$, $\mathrm{Cr}, \mathrm{As}, \mathrm{Cd}, \mathrm{Pb}$, and $\mathrm{Sb}(\mathrm{mg} / \mathrm{kg})$. The concentrations of major and trace elements reported by these authors are higher than those determined in the present study; in addition, the order of abundance was different. There are reports of concentrations such as $\mathrm{Mn}$ and $\mathrm{U}$ in potato peel [13]. These authors found concentrations of 1.8 to $4 \mathrm{mg} / \mathrm{kg}$ and 0.0626 to $0.5696 \mathrm{mg} / \mathrm{kg}$ for $\mathrm{Mn}$ and $\mathrm{U}$, respectively. Compared to this, the contents of $\mathrm{Mn}$ in the present study is higher, whereas the concentration of $\mathrm{U}$ is lower.

Table 5 shows a comparison of the nutrient values and trace elements that were found in walnuts in the present study together with values for walnuts from different parts of the world. In studies reported in the literature, As in walnuts is found below detection level. In contrast, in the present study the concentration of $\mathrm{Cd}$ was not detected whereas in the same matrix values up to $0.16 \mathrm{mg} / \mathrm{kg}$ were reported [50].

Table 5. Concentration of heavy metals and trace elements reported for walnuts in various parts of the world (literature values). Average concentration $(\mu \mathrm{g} / \mathrm{g}) \pm$ standard deviation.

\begin{tabular}{cccccc}
\hline Element & Spain [50] & Brazil [51] & Greece [52] & Present study & LP $^{\text {a }}$ \\
\hline $\mathrm{As}$ & $<$ LOD & $<$ LOD & - & $1.05 \pm 0.07$ & 0.05 \\
$\mathrm{Ca}$ & $507 \pm 63.5$ & - & - & $842.97 \pm 50.81$ & \\
$\mathrm{Cd}$ & $0.16 \pm 0.0198$ & $<\mathrm{LOD}$ & $<\mathrm{LOD}$ & $<\mathrm{LOD}$ & \\
$\mathrm{Cr}$ & $1.801 \pm 0.151$ & - & $0.53 \pm 0.003$ & $8.94 \pm 0.9$ & 1.0 \\
$\mathrm{Cu}$ & $4.9 \pm 0.1$ & $12.4 \pm 1.08$ & $17 \pm 1.2$ & $4.15 \pm 0.78$ & 4.5 \\
$\mathrm{Fe}$ & $21.5 \pm 1.3$ & $0.70 \pm 0.006$ & $45 \pm 3.1$ & $80.44 \pm 7.07$ & \\
$\mathrm{~K}$ & $4366 \pm 195$ & - & - & $4457 \pm 773.8$ & \\
$\mathrm{Mg}$ & $1276 \pm 59$ & - & $1330 \pm 41$ & $1422.8 \pm 133.4$ & \\
$\mathrm{Mn}$ & $81.2 \pm 2.6$ & $26.3 \pm 2.34$ & $26.5 \pm 2.3$ & $52.6 \pm 17.23$ & \\
$\mathrm{Na}$ & - & - & - & $206.1 \pm 7.74$ & \\
$\mathrm{P}$ & $2636 \pm 76.1$ & - & - & $2980.6 \pm 229.4$ & \\
$\mathrm{~Pb}$ & $<\mathrm{LOD}$ & $<\mathrm{LOD}$ & $<\mathrm{LOD}$ & $<\mathrm{LOD}$ & \\
$\mathrm{S}$ & - & - & - & $1089.8 \pm 78.15$ & \\
$\mathrm{Sb}$ & - & - & - & $2.54 \pm 1.59$ & \\
$\mathrm{U}$ & - & - & - & $0.052 \pm 0.01$ & \\
$\mathrm{Zn}$ & $25.5 \pm 0.5$ & $26 \pm 2.15$ & $22.6 \pm 3.0$ & $60.7 \pm 10.73$ & \\
\hline
\end{tabular}

$\mathrm{a}=$ permissible limit $(\mathrm{FAO} / \mathrm{WHO}, 2011) .<\mathrm{LOD}=$ result lower than the limits of detection of ICP-OES/ICP-MS. - = Not calculated. 
Furthermore, the concentration of elements-such as $\mathrm{Ca}, \mathrm{Cr}, \mathrm{Fe}$, and $\mathrm{Zn}$-was higher in the samples analyzed here. The contents of $\mathrm{K}, \mathrm{Mg}$, and $\mathrm{P}$ are of the same order as those reported in other studies. $\mathrm{Pb}$ is one of the trace elements that was below the detection level in walnuts.

The $\mathrm{Cu}$ values in the present study are lower than those reported by Muller et al. [51] and Momen et al. [52]. $\mathrm{Cu}$ is an essential element for plant physiological processes. However, if $\mathrm{Cu}$ is absorbed in excess it can be considered a toxic element that inhibits growth [53]. In the present study, the $\mathrm{Cu}$ contents in walnuts presented values up to $6.3 \mathrm{mg} / \mathrm{kg}$ in orchards such as Los Laureles and Viña Grande, passing the maximum allowable concentration for $\mathrm{Cu}$ in fruits (Table 3).

Concentrations of trace elements have been reported for several fruits and vegetables. One example of this is the contents of As in potato and eggplant, with values of 0.01 and $0.2 \mathrm{mg} / \mathrm{kg}$, respectively $[54,55]$. Furthermore, a study in Bangladesh reported a mean As concentration of $0.2 \mathrm{mg} / \mathrm{kg}$ in vegetables [54]. In both studies, the As contents in fruits and vegetables are lower than those analyzed here. In addition, $\mathrm{Cu}$ concentrations of 0.946 and $7.891 \mathrm{mg} / \mathrm{kg}$ have been reported for banana and mango, respectively [9]; which are similar to those determined in walnuts. Furthermore, $\mathrm{Cu}$ in walnuts analyzed here is nine times $(8-10 \mathrm{mg} / \mathrm{kg}$ ) higher than the maximum allowable concentration [56], in agreement with concentrations reported by Shaheen et al. [10] for bean $(1.11 \mathrm{mg} / \mathrm{kg})$ and carrot $(0.296 \mathrm{mg} / \mathrm{kg})$. Finally, a study in an area contaminated by a $\mathrm{U}$ mine [5] reports lower $\mathrm{Cr}$ values than here, found in tomato $(1 \mathrm{mg} / \mathrm{kg})$, banana $(1.5 \mathrm{mg} / \mathrm{kg})$, and papaya $(2.4 \mathrm{mg} / \mathrm{kg})$.

Concentrations of $\mathrm{K}$ found in walnuts in the present study range from 3925.6 to $5794 \mathrm{mg} / \mathrm{kg}$. In the literature, the highest values reported for this element are in tomato $(31,900 \mathrm{mg} / \mathrm{kg})$, parsley $(46,100 \mathrm{mg} / \mathrm{kg})$, and cucumber $(45,600 \mathrm{mg} / \mathrm{kg})$ [22]. The $\mathrm{S}$ contents in walnuts in the present study was lower compared to concentrations of 1760 and $2698 \mathrm{mg} / \mathrm{kg}$ in hazelnut and almonds, respectively [56].

For vegetables such as corn, cabbage, spinach, and parsley, Sb concentrations of $0.58,0.17,0.043$, and $0.24 \mathrm{mg} / \mathrm{kg}$ have been reported [37], which are lower than the concentration in walnuts in the present study. Additionally, $\mathrm{U}$ concentrations have been higher in foods such as wheat, $0.125 \mathrm{mg} / \mathrm{kg}$; and onion, $0.113 \mathrm{mg} / \mathrm{kg}$ [20]; whereas in watermelon [57], pepper, eggplant, and pepper [20] they have been $<0.1 \mathrm{mg} / \mathrm{kg}$. The latter are within the range of $U$ concentrations found in the present study.

$\mathrm{Zn}$ is considered one of the essential elements for growth and fruit production in walnut trees. This element is important for the biochemical and physiological processes in this plant. The $\mathrm{Zn}$ concentration in walnuts in the present study ranged from 44.9 to $74.6 \mathrm{mg} / \mathrm{kg}$, which is higher compared to several other vegetables: bean (4.75), onion (3.449), potato (3.019), and tomato $(2.0 \mathrm{mg} / \mathrm{kg})$ [9]. In addition, in areas severely contaminated with arsenic in Bangladesh, $\mathrm{Zn}$ values up to $50 \mathrm{mg} / \mathrm{kg}$ are reported for spinach and coriander [58].

\subsection{Transfer Factors (TF)}

Transfer factors (TF) were calculated from soil to leaves and nuts. In Figure 2, transfer factors for soil-leaves and soil-walnuts are shown.The transfer factors (TF) for trace metals in walnuts decrease in the order; $\mathrm{P}>\mathrm{S}>\mathrm{K}>\mathrm{Zn}>\mathrm{Sb}>\mathrm{Na}>\mathrm{Cu}>\mathrm{Mg}>\mathrm{Cr}>\mathrm{Ca}>\mathrm{Mn}>\mathrm{U}>\mathrm{As}>\mathrm{Fe}$. $\mathrm{P}$ has the highest TF for all the walnut orchards, ranging from 1.19 to 8.58. This range is similar to a TF from 1 to 3.53 reported for tomato, parsley, and cucumber [22]. P does not present a human health risk because this analyte is an essential macronutrient for all living beings. Additionally, the TF for Zn from soil to walnut ranged from 0.3945 to 0.9901 . These values are similar to TF values reported in the literate, from 0.2 to 5 in vegetables [4,22].

The TF of $\mathrm{Cr}$ in walnuts ranges from 0.1763 to 0.2543 . This is higher than the TF reported for vegetables such as corn, eggplant, mint, pepper, tomato [4], and parsley [22], which does not exceed 0.03. The high TF for Cr from soil to walnut in the present study is important because of the high toxicity of $\mathrm{Cr}$. Previous studies have established that $\mathrm{Cr}$ does not easily translocate within the plant, for which it is mainly concentrated in the roots. One of the most important factors is the $\mathrm{pH}$, due to its effect on the solubility of the $\mathrm{Cr}$ species, and therefore its sorption in the soil and its bioavailability. When the $\mathrm{pH}$ is between 6 and $8.5, \mathrm{Cr}$ is precipitated as $\mathrm{Cr}(\mathrm{OH})_{3}$ and is generally not available to the 
plant $[4,11]$. However, when the $\mathrm{pH}$ ranges between neutral and alkaline, the specie $\mathrm{Cr}^{6+}$ is present in very soluble forms, for example $\mathrm{Na}_{2} \mathrm{CrO}_{4}$ [59]. In the present study, the $\mathrm{pH}$ was between 8.3 and 8.8 . Therefore, these alkaline $\mathrm{pH}$ values promote the solubility of $\mathrm{Cr}$ and its availability to the plant and the walnuts. The elements $\mathrm{Ca}, \mathrm{Fe}, \mathrm{Mn}$, and $\mathrm{U}$ had a TF of $\ll 1$, in other words, they do not have a high transfer from the soil to the walnuts.

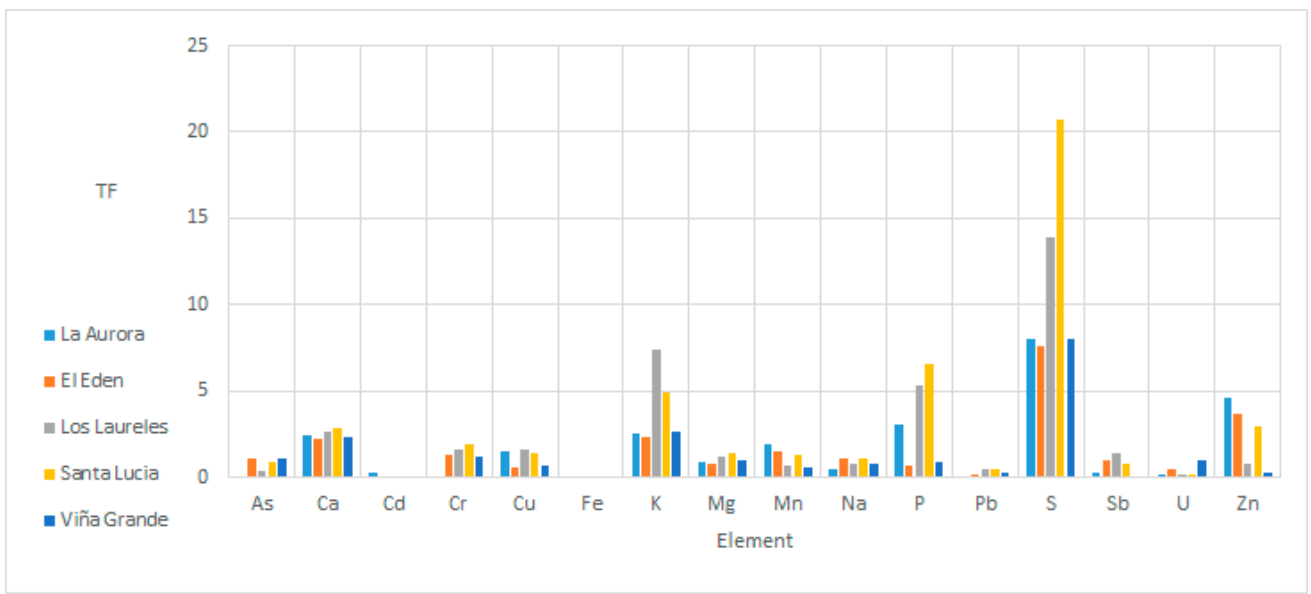

(a)

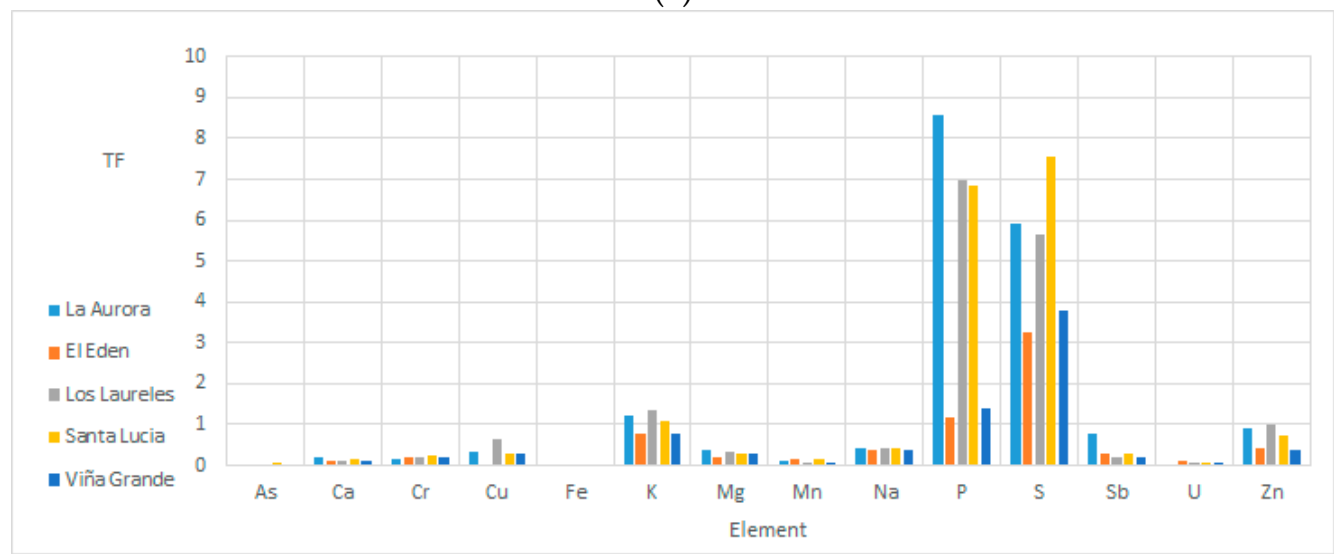

(b)

Figure 2. Transfer factors calculated: (a) from soil to leaves; and (b) from soil to walnut.

The results for the TF of soil/leaves in walnuts indicates a high transfer of the nutrients $\mathrm{Ca}, \mathrm{Cu}$, $\mathrm{K}, \mathrm{Mg}, \mathrm{Mn}, \mathrm{P}, \mathrm{S}$, and $\mathrm{Zn}$. In the particular case of $\mathrm{Cu}$, the TF ranges from 0.610 to 1.619. A study on spinach, cabbage, and celery leaves reported a mean TF of 0.02 [28]. The soil/leaves TF indicates a high transfer of As in the orchards El Edén and Viña Grande, with a TF of 1.097 and 1.137, respectively. This could be the result of the age of the trees, since these orchards have the oldest trees (approximately 60 years). In contrast, in the orchard La Aurora the TF for As is very low, because here the trees are younger. A study in vegetable leaves (spinach, celery, cabbage) reported TF values of 0.01 for As [28].

It is important to note that the behavior of $\mathrm{Cd}$ is opposite to that of the trace elements $\mathrm{As}, \mathrm{Cr}, \mathrm{Pb}$, and $\mathrm{Sb}$. In the orchard La Aurora, Cd has a TF of 0.262, in contrast to the low TF in the orchards with older trees. Possibly, $\mathrm{Cd}$ is inversely correlated with tree age. Therefore, it is suggested that $\mathrm{Cd}$ is only transferred to the leaves when the tree is younger and the plant has a higher need for nutrients for its growth.

Moreover, in the leaves positive correlations were found between $\mathrm{Ca}$ and $\mathrm{Pb}, \mathrm{Cr}$ and $\mathrm{P}$, and $\mathrm{Cr}$ and $\mathrm{Fe}(P<0.05)$. This behavior could be explained on the basis of chemical congeners. Taking into account the oxidation states and atomic radii of the elements; the plant could be taking $\mathrm{Pb}(2+)$ as a chemical congener to $\mathrm{Ca}^{2+}$, since their atomic radii are very similar $(\sim 1.8 \AA)$. Similarly, $\mathrm{Cr}$ and Fe have oxidation states of $3+$, with atomic radii of $1.4 \AA$. Moreover, because the concentration of $\mathrm{Cr}$ in 
the leaves is higher than the concentration of $\mathrm{Cr}$ in the soil, it is suggested that the walnut tree leaves behave as hyperaccumulators of this analyte.

\subsection{Hazard Risk Quotients (HQ)}

In Table 6, the HQ are presented for the elements that were analyzed, as well as a comparison with values reported in several studies. This was determined for a consumption of $30 \mathrm{~g}$ per day. The HQ decreases in the following order; $\mathrm{Sb}>\mathrm{As}>\mathrm{Mn}>\mathrm{Fe}>\mathrm{Cr}>\mathrm{Zn}>\mathrm{Cu}>\mathrm{P}>\mathrm{Mg}>\mathrm{Ca}>\mathrm{K}>\mathrm{Na}$. When the HQ is equal to or higher than one, the analyte presents a health risk. The HQs of $\mathrm{Sb}, \mathrm{Cr}, \mathrm{As}$, and $\mathrm{Zn}$ are representative indicate a health risk due to their high concentration in walnuts and their toxicity. Furthermore, these elements are associated with cancer risk [10]. A high HQ is observed for As, with a value of 0.1250 . This value does not represent a health risk. However, it is important to note that the prolonged ingestion of As may pose a health risk.

Table 6. Hazard risk quotients for walnut $(\mathrm{HQ})$ and those reported in the literature $\left(\mathrm{HQ}^{*}\right)$.

\begin{tabular}{|c|c|c|c|c|c|c|}
\hline Element & $\begin{array}{c}C \\
(\mu g / g)\end{array}$ & $\begin{array}{l}\text { Intake } \\
(\mu \mathrm{g} / \mathrm{kg} / \text { día })\end{array}$ & $\begin{array}{c}\text { TDI } \\
(\mu \mathrm{g} / \text { día })\end{array}$ & HQ & $\mathrm{HQ}^{*}$ & \\
\hline As & 1.05 & 0.4375 & 3.5 & 0.1250 & $\begin{array}{c}\mathrm{T}<0.142 \\
\mathrm{Py}=0.353 \\
\mathrm{C}=0.222\end{array}$ & (Noli \& Tsamos, 2016) \\
\hline $\mathrm{Ca}$ & 842.97 & 351.24 & $1,000,000$ & 0.0004 & - & \\
\hline \multirow[t]{2}{*}{$\mathrm{Cr}$} & 8.94 & 3.73 & 1500 & 0.0025 & $\begin{array}{c}\mathrm{T}<0.001 \\
\mathrm{Py}=0.002 \\
\mathrm{C}=0.001\end{array}$ & (Noli \& Tsamos, 2016) \\
\hline & & & & & $\begin{array}{c}\mathrm{C}=0.00006 \\
\mathrm{~T}=0.00044 \\
\mathrm{P}=0.0023\end{array}$ & (Cherfi et al., 2015) \\
\hline $\mathrm{Cu}$ & 4.15 & 1.73 & 900 & 0.0019 & $\begin{array}{l}C=0.006 \\
T=0.010 \\
P=0.203\end{array}$ & (Cherfi et al., 2015) \\
\hline $\mathrm{Fe}$ & 80.44 & 33.52 & 8000 & 0.0042 & - & \\
\hline K & 4457 & 1857.08 & $4,700,000$ & 0.0004 & - & \\
\hline $\mathrm{Mg}$ & 1422.8 & 592.83 & 420,000 & 0.0014 & - & \\
\hline Mn & 52.6 & 21.92 & 2300 & 0.0095 & - & \\
\hline $\mathrm{P}$ & 2980.6 & 1241.92 & 700,000 & 0.0018 & - & \\
\hline $\mathrm{Na}$ & 206.1 & 85.88 & $1,500,000$ & 0.0001 & - & \\
\hline $\mathrm{Sb}$ & 2.54 & 1.06 & 0.86 & 1.2306 & - & \\
\hline \multirow[t]{2}{*}{$\mathrm{Zn}$} & 60.7 & 25.29 & 11000 & 0.0023 & $\begin{array}{c}\mathrm{T}=0.018 \\
\mathrm{Py}=0.009 \\
\mathrm{C}=0.020\end{array}$ & (Noli \& Tsamos, 2016) \\
\hline & & & & & $\begin{array}{l}C=0.0009 \\
T=0.0058 \\
P=0.0279\end{array}$ & (Cherfi et al., 2015) \\
\hline
\end{tabular}

$\mathrm{C}=$ Cucumber, $\mathrm{T}$ = Tomato, $\mathrm{P}=$ Potato, $\mathrm{Py}=$ Parsley, $\mathrm{W}=$ Walnut. - = not calculated.

The HQ for $\mathrm{Sb}$ was 1.23. In the literature there are no studies on HQs for Sb. The HQ that was determined for As in walnuts is slightly lower than the HQs reported by Noli and Tsamos [22] for tomato $(<0.143)$, parsley $(0.353)$, and cucumber $(0.222)$. It is important to note that this study took place in an area close to an electric power plant that, because of the ash produced, has contaminated the environment. Furthermore, a study on fruits and vegetables reported HQ values of 0.032 for mango, 0.130 for bean, 0.043 for carrot, 0.01 for onion, 0.023 for potato, and 0.043 for tomato [9]. 
In the present study, the $\mathrm{HQ}$ for $\mathrm{Cr}$ in walnuts was 0.0025 . This value does not represent a health risk. A study by Noli and Tsamos [22] reported a HQ for $\mathrm{Cr}$ of $<0.001$ for tomato, 0.009 for parsley, and 0.020 for cucumber. Another study on fruits and vegetables in Bangladesh found HQs for $\mathrm{Cr}$ of 0.0004 , 0.002 , and 0.006 for banana, bean, and tomato, respectively [9]. Finally, a study in Algeria found HQ values for $\mathrm{Cr}$ of 0.000064 for cucumber, 0.00044 for tomato, and 0.0023 for potato [10]. It is remarkable that the HQ values in the present study correspond to the highest values for $\mathrm{Cr}$.

\subsection{Correlation Analysis}

In Figure 3, the results of the Cluster Analysis that was performed with SAS 9.0 are shown, where the clustering of the orchards can be seen. It should be noted that this cluster analysis was performed with the data of the samples: nuts, shells, soils, leaves, and water of every orchard analyzed (El Edén, La Aurora, Viña Grande, Los Laureles, and Santa Lucía), with the analytes: As, Ca, Cd, Cr, $\mathrm{Cu}, \mathrm{Fe}, \mathrm{K}, \mathrm{Mg}, \mathrm{Mn}, \mathrm{Na}, \mathrm{P}, \mathrm{Pb}, \mathrm{S}, \mathrm{Sb}, \mathrm{U}$, and $\mathrm{Zn}$. Thus, 80 variables were analyzed.

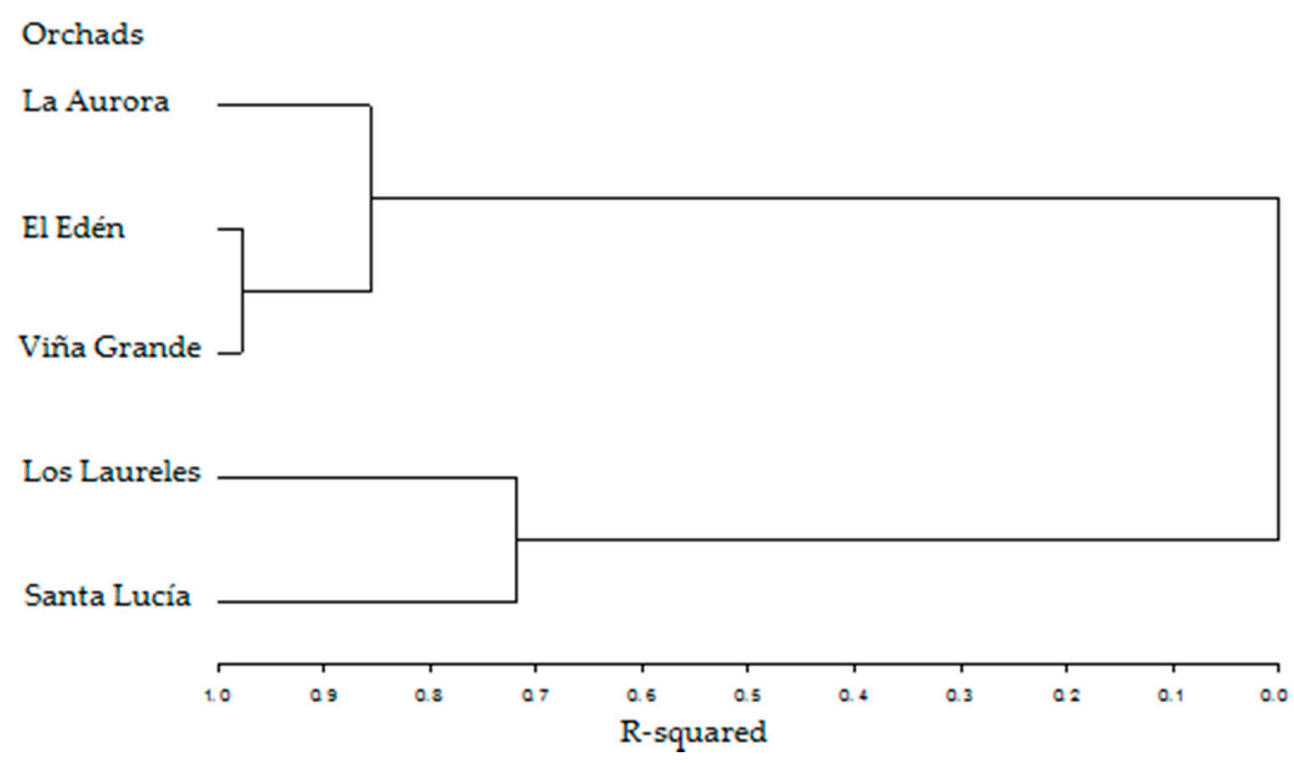

Figure 3. Tree diagram with the clusters of the orchards.

In Figure 3, the first group that can be observed contains the orchards El Edén and Viña Grande, both orchards with trees of the same age (approximately 60 years old). A second cluster contains the previous orchards as well as La Aurora. This is attributed to the similarity in chemical soil characteristics of these three orchards. Finally, a third cluster combines the orchards Santa Lucía and Los Laureles, with trees that have an average age of 35 years.

\section{Conclusions}

In the present study, the distribution of trace elements and nutrients in the interaction water-soil-walnut tree was determined. In the irrigation water samples, $\mathrm{As}, \mathrm{Cr}$, and $\mathrm{Pb}$, showed concentrations above the maximum allowable limits outlined in the Mexican legislation on irrigation water quality. Due to groundwater is used for human consumption, irrigation, and livestock feed a monitoring program and technologies to remove the contaminants are needed in order to improve the water quality.

High levels of $\mathrm{As}, \mathrm{Cr}, \mathrm{Pb}$, and $\mathrm{Sb}$ were found in the walnut tree leave samples, indicating a possible tendency to hyperaccumulate these trace elements in walnut trees. These analytes solubilize from soil-plant, which is attributed to the high soil pH. Currently, the leaf litter is burned, however, it is important to implement adequate management practices for its final disposition. 
The elemental transference obtained for the interactions water-soil, soil-leaves, soil-nut indicate possible chemical congeners when comparing to the chemical radio ionic properties and oxidation states, which is supported by the correlation analysis. This results in the uptake of $\mathrm{Pb}^{2+}$ instead of $\mathrm{Ca}^{2+}, \mathrm{Cr}^{3+}$ instead of $\mathrm{P}^{3+}$, and $\mathrm{Cr}^{3+}$ instead of $\mathrm{Fe}^{3+}$ by the plant.

The $\mathrm{Cr}$ concentrations in walnuts were up to 10 times higher than the reference value established by $\mathrm{FAO} / \mathrm{WHO}$. Sb concentrations in walnuts were also high. The hazard risk quotient was high for $\mathrm{Sb}$, indicating a health risk. On the other hand, the hazard risk quotients for As and $\mathrm{Cr}$ did not indicate a potential health risk. However, it is important to consider that the health risk increases when exposure through consumption takes place over a prolonged period of time, even in low concentrations.

Finally, the trace elements could be transferred form the water to the soil and increase the availability of toxic elements to the walnut tree. Hence, it is suggested that the Mexican authorities establish a legislation with maximum allowable concentrations for trace elements in fruits and vegetables, to implement monitoring and evaluate health risks.

Author Contributions: A.C.-T. participated in the sampling collection, sample processing, spectra analysis, results interpretation, and statistical data processing. C.P.-A. participated in the results interpretation and discussion of the results. L.C.-P. contributed to the interpretation and the discussion of the results. E.S.-E. contributed with statistical data processing and discussion of the results. M.R.-V. participated in sampling collection, sample processing, spectra analysis, results interpretation, discussion, and article writing. She is the corresponding author.

Funding: This research was financially supported by CONACyT, in the Proyect CB-2011-01-16697.

Acknowledgments: We say thanks for the technical support given by CIMAV (Centro de Investigacion en Materiales Avanzados) and SGM (Servicio Geológico Mexicano).

Conflicts of Interest: The authors declare no conflict of interest.

\section{References}

1. Beygi, M.; Jalali, M. Background levels of some trace elements in calcareous soils of the Hamedan Province, Iran. CATENA 2018, 162, 303-316. [CrossRef]

2. Steinnes, E.; Lierhagen, S. Geographical distribution of trace elements in natural surface soils: Atmospheric influence from natural and anthropogenic sources. Appl. Geochem. 2018, 88, 2-9. [CrossRef]

3. Funes Pinter, I.; Salomon, M.V.; Gil, R.; Mastrantonio, L.; Bottini, R.; Piccoli, P. Arsenic and trace elements in soil, water, grapevine and onion in Jáchal, Argentina. Sci. Total Environ. 2018, 615, 1485-1498. [CrossRef] [PubMed]

4. Avci, H.; Deveci, T. Assessment of trace element concentrations in soil and plants from cropland irrigated with wastewater. Ecotoxicol. Environ. Saf. 2013, 98, 283-291. [CrossRef] [PubMed]

5. Basha, A.M.; Yasovardhan, N.; Satyanarayana, S.V.; Reddy, G.V.S.; Vinod Kumar, A. Trace metals in vegetables and fruits cultivated around the surroundings of Tummalapalle uranium mining site, Andhra Pradesh, India. Toxicol. Rep. 2014, 1, 505-512. [CrossRef] [PubMed]

6. Matos-Reyes, M.N.; Cervera, M.L.; Campos, R.C.; de la Guardia, M. Total content of As, Sb, Se, Te and Bi in Spanish vegetables, cereals and pulses and estimation of the contribution of these foods to the Mediterranean daily intake of trace elements. Food Chem. 2010, 122, 188-194. [CrossRef]

7. Darwish, M.A.G.; Pöllmann, H. Trace elements assessment in agricultural and desert soils of Aswan area, south Egypt: Geochemical characteristics and environmental impacts. J. Afr. Earth Sci. 2015, 112, 358-373. [CrossRef]

8. Barakat, M.A. New trends in removing heavy metals from industrial wastewater. Arab. J. Chem. 2011, 4, 361-377. [CrossRef]

9. Shaheen, N.; Irfan, N.M.; Khan, I.N.; Islam, S.; Islam, M.S.; Ahmed, M.K. Presence of heavy metals in fruits and vegetables: Health risk implications in Bangladesh. Chemosphere 2016, 152, 431-438. [CrossRef] [PubMed]

10. Cherfi, A.; Achour, M.; Cherfi, M.; Otmani, S.; Morsli, A. Health risk assessment of heavy metals through consumption of vegetables irrigated with reclaimed urban wastewater in Algeria. Process Saf. Environ. Prot. 2015, 98, 245-252. [CrossRef] 
11. Kabata-Pendias, A. Soil-plant transfer of trace elements-an environmental issue. Geoderma 2004, 122, 143-149. [CrossRef]

12. Cary, L.; Surdyk, N.; Psarras, G.; Kasapakis, I.; Chartzoulakis, K.; Sandei, L.; Guerrot, C.; Pettenati, M.; Kloppmanna, W. Short-term assessment of the dynamics of elements in wastewater irrigated Mediterranean soil and tomato fruits through sequential dissolution and lead isotopic signatures. Agric. Water Manag. 2015, 155, 87-99. [CrossRef]

13. Neves, M.O.; Figueiredo, V.R.; Abreu, M.M. Transfer of U, Al and Mn in the water-soil-plant (Solanum tuberosum L.) system near a former uranium mining area (Cunha Baixa, Portugal) and implications to human health. Sci. Total Environ. 2012, 416, 156-163. [CrossRef] [PubMed]

14. Odabasi, M.; Tolunay, D.; Kara, M.; Ozgunerge Falay, E.; Tuna, G.; Altiok, H.; Dumanoglu, Y.; Bayram, A.; Elbir, T. Investigation of spatial and historical variations of air pollution around an industrial region using trace and macro elements in tree components. Sci. Total Environ. 2016, 550, 1010-1021. [CrossRef] [PubMed]

15. Simmons, A. Natural Analogue studies at Peña Blanca, México. In Proceedings of the 2005 Salt Lake City Annual Meeting, Salt Lake City, UT, USA, 16-19 October 2005.

16. Rodriguez-Pineda, J.A.; Goodell, P.; Dobson, P.F.; Walton, J.; Oliver, R.; Garza, D.L.; Harder, S. Regional Hidrology of the Nopal I site Sierra de Peña Blanca, Chihuahua México. In Proceedings of the 2005 Salt Lake City Annual Meeting, Salt Lake City, UT, USA, 16-19 October 2005.

17. Degueldre, C.; Kline, A. Study of thorium association and surface precipitation on colloids. Earth Planet. Sci. Lett. 2007, 264, 104-113. [CrossRef]

18. Chabaux, F.; Riotte, J.; Dequincey, O. U-Th-Ra fractionation during weathering and river transport. In Uranium-Series Goechemestry Reviews in Mineralogy and Geochemestry; Mineralogical Soc. of America: Washinton, DC, USA, 2003; Volume 52, pp. 533-576.

19. Unno, Y.; Tsukada, H.; Takeda, A.; Takaku, Y.; Hisamatsu, S. Soil-soil solution distribution coefficient of soil organic matter is a key factor for that of radioiodide in surface and subsurface soils. J. Environ. Radioact. 2017, 169-170, 131-136. [CrossRef] [PubMed]

20. Al-Hamarneh, I.F.; Alkhomashi, N.; Almasoud, F.I. Study on the radioactivity and soil-to-plant transfer factor of 226Ra, 234U and 238U radionuclides in irrigated farms from the northwestern Saudi Arabia. J. Environ. Radioact. 2016, 160, 1-7. [CrossRef] [PubMed]

21. Martínez-Aguirre, A.; Periáñez, R. Soil to plant transfer of 226Ra in a marsh area: Modelling application. J. Environ. Radioact. 1998, 39, 199-213. [CrossRef]

22. Noli, F.; Tsamos, P. Concentration of heavy metals and trace elements in soils, waters and vegetables and assessment of health risk in the vicinity of a lignite-fired power plant. Sci. Total Environ. 2016, 563-564, 377-385. [CrossRef] [PubMed]

23. Jolly, Y.N.; Islam, A.; Akbar, S. Transfer of metals from soil to vegetables and possible health risk assessment. SpringerPlus 2013, 2, 385. [CrossRef] [PubMed]

24. Xu, D.; Zhou, P.; Zhan, J.; Gao, Y.; Dou, C.; Sun, Q. Assessment of trace metal bioavailability in garden soils and health risks via consumption of vegetables in the vicinity of Tongling mining area, China. Ecotoxicol. Environ. Saf. 2013, 90, 103-111. [CrossRef] [PubMed]

25. Warming, M.; Hansen, M.G.; Holm, P.E.; Magid, J.; Hansen, T.H.; Trapp, S. Does intake of trace elements through urban gardening in Copenhagen pose a risk to human health? Environ. Pollut. 2015, 202, 17-23. [CrossRef] [PubMed]

26. CONAGUA. Ley Federal de Derechos, Disposiciones Aplicables en Materia de Aguas Nacionales; Agua, C.N.D., Ed.; Gobierno de la Republica Mexico: Mexico City, Mexico, 2017; pp. 1-166.

27. Ayers, R.S.; Westcot, D.W. Water Quality for Agriculture. Rome: FAO Irrigation and Drainage Paper No. 29. En: http://www.fao.org/docrep/003/T0234E/T0234E00.htm; Food and Agriculture Organization: Rome, Italy, 1985.

28. Hu, W.; Huang, B.; Tian, K.; Holm, P.E.; Zhang, Y. Heavy metals in intensive greenhouse vegetable production systems along Yellow Sea of China: Levels, transfer and health risk. Chemosphere 2017, 167, 82-90. [CrossRef] [PubMed]

29. Xiao, J.; Jin, Z.; Wang, J. Geochemistry of trace elements and water quality assessment of natural water within the Tarim River Basin in the extreme arid region, NW China. J. Geochem. Explor. 2014, 136, 118-126. [CrossRef] 
30. Khaska, M.; Gal La Salleab, C.; Sassine, L.; Cary, L.; Bruguier, O.; Verdouxa, P. Arsenic and metallic trace elements cycling in the surface water-groundwater-soil continuum down-gradient from a reclaimed mine area: Isotopic imprints. J. Hydrol. 2018, 558, 341-355. [CrossRef]

31. Grande, J.A.; Santisteban, M.; de la Torre, M.L.; Dávila, J.M.; Pérez-Ostalé, E. Map of impact by acid mine drainage in the river network of The Iberian Pyrite Belt (Sw Spain). Chemosphere 2018, 199, 269-277. [CrossRef] [PubMed]

32. FAO/WHO. Joint FAO/WHO Food Standards Programme Codex Committee on Contaminants in Foods; FAO: Geneva, Switzerland, 2011; pp. 64-89.

33. Hartley, W.; Edwards, R.; Lepp, N.W. Arsenic and heavy metal mobility in iron oxide-amended contaminated soils as evaluated by short- and long-term leaching tests. Environ. Pollut. 2004, 131, 495-504. [CrossRef] [PubMed]

34. Margenat, A.; Matamoros, V.; Díez, S.; Cañameras, N.; Comas, J.; Bayona, J.M. Occurrence of chemical contaminants in peri-urban agricultural irrigation waters and assessment of their phytotoxicity and crop productivity. Sci. Total Environ. 2017, 599-600, 1140-1148. [CrossRef] [PubMed]

35. Pauling, L. General Chemistry; Dover Publications: New York, NY, USA, 2014.

36. Servicio Geológico Mexicano (SGM). Carta Geológica-Minera Ciudad Delicias H13-11; Chihuahua, S.G.M., Ed.; Secretaria de Economia Mexico: Mexico City, Mexico, 2000.

37. Hammel, W.; Debus, R.; Steubing, L. Mobility of antimony in soil and its availability to plants. Chemosphere 2000, 41, 1791-1798. [CrossRef]

38. El-Taher, A.; García-Tenorio, R.; Khater, A.E.M. Ecological impacts of Al-Jalamid phosphate mining, Saudi Arabia: Soil elemental characterization and spatial distribution with INAA. Appl. Radiat. Isot. 2016, 107, 382-390. [CrossRef] [PubMed]

39. Vassilev, S.V.; Vassileva, C.G.; Baxter, D. Trace element concentrations and associations in some biomass ashes. Fuel 2014, 129, 292-313. [CrossRef]

40. Uluozlu, O.D.; Tuzen, M.; Mendil, D.; Soylak, M. Assessment of trace element contents of chicken products from turkey. J. Hazard. Mater. 2009, 163, 982-987. [CrossRef] [PubMed]

41. Ferguson, J.F.; Gavis, J. A review of the arsenic cycle in natural waters. Water Res. 1972, 6, $1259-1274$. [CrossRef]

42. Deljanin, I.; Antanasijević, D.; Bjelajac, A.; Urošević, M.A.; Nikolić, M.; Perić-Grujić, A.; Ristić, M. Chemometrics in biomonitoring: Distribution and correlation of trace elements in tree leaves. Sci. Total Environ. 2016, 545-546, 361-371. [CrossRef] [PubMed]

43. Tomašević, M.; Aničić, M.; Jovanović, L.; Perić-Grujić, A.; Ristić, M. Deciduous tree leaves in trace elements biomonitoring: A contribution to methodology. Ecol. Indic. 2011, 11, 1689-1695. [CrossRef]

44. Aničić, M.; Spasić, T.; Tomašević, M.; Rajšić, S.; Tasić, M. Trace elements accumulation and temporal trends in leaves of urban deciduous trees (Aesculus hippocastanum and Tilia spp.). Ecol. Indic. 2011, 11, 824-830. [CrossRef]

45. Perea Portillo, E.; Dámaris Leopoldina, O.B.; Ofelia Adriana, H.R.; Dalila Jacqueline, E.A.; Jaime Javier, M.T.; Gustavo Rogelio, L.O. El zinc como promotor de crecimiento y fructificación en el nogal pecanero. Tecnociencia Chihuah. 2010, 4, 64-71.

46. Naozuka, J.; Carvalho Vieira, E.; Nascimento, A.N.; Oliveira, P.V. Elemental analysis of nuts and seeds by axially viewed ICP OES. Food Chem. 2011, 124, 1667-1672. [CrossRef]

47. Atanasov, A.G.; Sabharanjak, S.M.; Zengin, G.; Mollica, A.; Szostak, A.; Simirgiotis, M.; Huminiecki, Ł.; Horbanczuk, O.K.; Nabavi, S.M.; Mocan, A. Pecan nuts: A review of reported bioactivities and health effects. Trends Food Sci. Technol. 2018, 71, 246-257. [CrossRef]

48. Stuetz, W.; Schlörmann, W.; Glei, M. B-vitamins, carotenoids and $\alpha$ - $/ \gamma$-tocopherol in raw and roasted nuts. Food Chem. 2017, 221, 222-227. [CrossRef] [PubMed]

49. Cardoso, B.R.; Duarte, G.B.S.; Reis, B.Z.; Cozzolino, S.M.F. Brazil nuts: Nutritional composition, health benefits and safety aspects. Food Res. Int. 2017, 100, 9-18. [CrossRef] [PubMed]

50. Moreda-Piñeiro, J.; Herbello-Hermelo, P.; Domínguez-González, R.; Bermejo-Barrera, P.; Moreda-Piñeiro, A. Bioavailability assessment of essential and toxic metals in edible nuts and seeds. Food Chem. 2016, 205, 146-154. [CrossRef] [PubMed] 
51. Muller, C.C.; Muller, A.L.H.; Pirola, C.; Duarte, F.A.; Flores, E.M.M.; Muller, E.I. Feasibility of nut digestion using single reaction chamber for further trace element determination by ICP-OES. Microchem. J. 2014, 116, 255-260. [CrossRef]

52. Momen, A.A.; Zachariadis, G.A.; Anthemidis, A.N.; Stratis, J.A. Use of fractional factorial design for optimization of digestion procedures followed by multi-element determination of essential and non-essential elements in nuts using ICP-OES technique. Talanta 2007, 71, 443-451. [CrossRef] [PubMed]

53. Alaoui-Sossé, B.; Genet, P.; Vinit-Dunand, F.; Toussaint, M.-L.; Epron, D.; Badot, P.-M. Effect of copper on growth in cucumber plants (Cucumis sativus) and its relationships with carbohydrate accumulation and changes in ion contents. Plant Sci. 2004, 166, 1213-1218. [CrossRef]

54. Sultana, M.S.; Jolly, Y.N.; Yeasmin, S.; Islam, A.; Satter, S.; Tareq, S.M. Chapter 12-Transfer of Heavy Metals and Radionuclides from Soil to Vegetables and Plants in Bangladesh A2-Hakeem, Khalid Rehman. In Soil Remediation and Plants; Sabir, M., Öztürk, M., Mermut, A.R., Eds.; Academic Press: San Diego, CA, USA, 2015; pp. 331-366.

55. Alam, M.M.G.; Snow, E.T.; Tanaka, A. Arsenic and heavy metal contamination of vegetables grown in Samta village, Bangladesh. Sci. Total Environ. 2003, 308, 83-96. [CrossRef]

56. FAO/WHO. REPORT OF THE 33rd SESSION OF THE CODEX COMMITTEE ON FOOD ADDITIVES AND CONTAMINANTS. Codex Alimentarius Commission [FAO/WHO], Food Additives and Contaminants. Join FAO/WHO Food Standars Program. ALINORM 01/12A 2001 [cited 2018; 1-289]. Available online: Htp:/ / ftp.fao.org/Codex/Reports / Alinorm01/al0112ae.pdf (accessed on 14 February 2018).

57. Al-Kharouf, S.J.; Al-Hamarneh, I.F.; Dababneh, M. Natural radioactivity, dose assessment and uranium uptake by agricultural crops at Khan Al-Zabeeb, Jordan. J. Environ. Radioact. 2008, 99, 1192-1199. [CrossRef] [PubMed]

58. Rahman, M.M.; Asaduzzaman, M.; Naidu, R. Consumption of arsenic and other elements from vegetables and drinking water from an arsenic-contaminated area of Bangladesh. J. Hazard. Mater. 2013, 262, 1056-1063. [CrossRef] [PubMed]

59. James, B.R. Peer Reviewed: The Challenge of Remediating Chromium-Contaminated Soil. Environ. Sci. Technol. 1996, 30, 248A-251A. [CrossRef] [PubMed] 